Abstracta Iranica

Revue bibliographique pour le domaine irano-aryen

Volume 40-41 | 2019

Comptes rendus des publications de 2017-2018

\title{
Anna Beselin. Knots, Art \& History: The Berlin Carpet Collection
}

Yuka Kadoi

\section{Q OpenEdition \\ 12 Journals}

\section{Electronic version}

URL: http://journals.openedition.org/abstractairanica/51923

DOI: 10.4000/abstractairanica.51923

ISBN: 1961-960X

ISSN: 1961-960X

Publisher:

CNRS (UMR 7528 Mondes iraniens et indiens), Éditions de l'IFRI

Electronic reference

Yuka Kadoi, "Anna Beselin. Knots, Art \& History: The Berlin Carpet Collection", Abstracta Iranica [Online],

Volume 40-41 | 2019, document 5, Online since 30 December 2019, connection on 17 April 2021. URL: http://journals.openedition.org/abstractairanica/51923 ; DOI: https://doi.org/10.4000/ abstractairanica.51923

This text was automatically generated on 17 April 2021.

Tous droits réservés 


\title{
Anna Beselin. Knots, Art \& History: The Berlin Carpet Collection
}

\author{
Yuka Kadoi
}

\section{REFERENCES}

Anna Beselin. Knots, Art \& History: The Berlin Carpet Collection. Milan: Skira, 2018, 224 p., 138 colour ill. ISBN: 9788857239125

1 Among the celebrated carpet collections in European museums, the Museum of Islamic Art in Berlin possesses one of the oldest and finest collections of this kind. Although several attempts have been made to publicise the Berlin carpet collection in the past, Knots, Art \& History marks the first publication of the united carpet collection of the Museum in English.

2 This book is divided into the following two main sections: art-historical notes (pp. 14-39) and a catalogue of select examples (46 out of some 500 carpets from the Berlin collection) (pp.40-205). The appendix contains a concordance and a bibliography, while footnotes / endnotes are not included in this book. The arthistorical section of this book narrates the Berlin collection's eventful history and in turn corresponds to Germany's momentous 20th-century history, spanning from World War 1, World War II, Cold War to the Reunification. Each catalogue entry is richly illustrated, including all essential pieces of information (place and date of production, inventory number, provenance, size, medium and, most importantly, knot count, which is based on $10 \mathrm{~cm}$ in the vertical [V] and $10 \mathrm{~cm}$ in the horizontal [H] as general guidelines due to the variation of knot density within a carpet) and 1-2 page arthistorical descriptions.

In this review article, I focus on not only antique rugs attributed to modern-day Iran but also carpets coming from the wider Persian cultural sphere, such as Caucasian and Indian examples. The sub-section entitled "Persian Carpets" (pp. 156-187) features eight classical examples from the Berlin collection, such as the "Vase Carpet" (no. 37; a 
fragmentary late sixteenth-century carpet decorated with floral and vase patterns, hence known as the "Vase Carpet"; acquired in 1899 by Friedrich Sarre [1865-1945]); the "Polonaise Carpet" (no. 38; an early seventeenth-century carpet, also called "Polish carpet"; it was initially misattributed to Poland, because the example of this type which first came to be known in Europe had Polish provenance); and the "Garden Carpet" (no. 42: a late eighteenth-century carpet with the four-part garden [chahar-bagh] design; the largest carpet in the Berlin collection; 879 × $291 \mathrm{~cm}$ ).

4 The Caucasian group of carpets (nos. 43-44) is mostly associated with the type of rugs with the highly stylized dragon design, known as the "Dragon Carpet". Both have connections with Wilhelm von Bode (1845-1929). Only one example from the Mughal group is featured in this book. The monumentality of the spiral vine carpet (no. 46) is emphasised not only by its generous size $(768 \times 298 \mathrm{~cm})$ but also its horizontal arrangement of design.

5 The absence of source citation in this book indicates that Knots, Art \& History was intended for a broad readership rather than for a specialist circle. Yet it successfully sheds much-deserved light on the united carpet collection in reunified Berlin as the outcome of the author's many years of conservation practice and art-historical studies.

\section{AUTHORS}

\section{YUKA KADOI}

University of Vienna 